\title{
Clinical Observations Category
}

National Cancer Institute

\section{Source}

National Cancer Institute. Clinical Observations Category. NCI Thesaurus. Code C119797.

A classification of clinical observation data. 